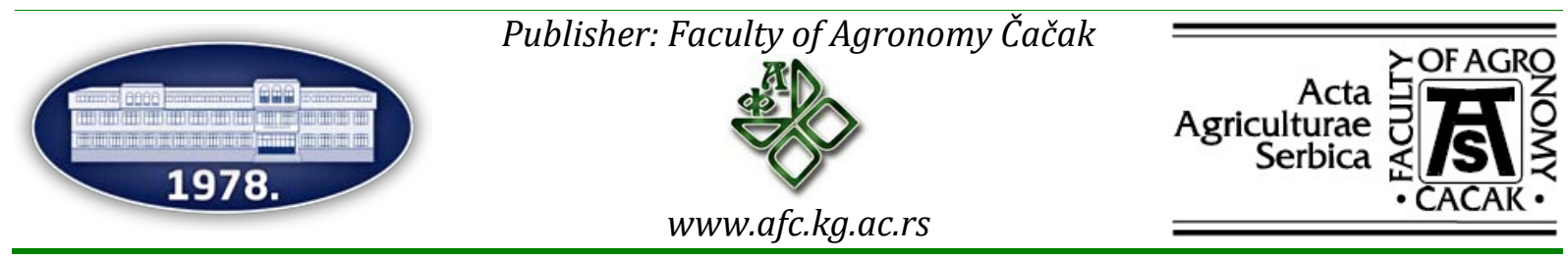

\title{
Paradigm of coinfection with viral and bacterial agents causing bovine respiratory disease complex (BRDC) in Central Serbia
}

\author{
Kazimir Matović ${ }^{2}$, Vladimir S. Kurćubić ${ }^{*}$, Radojica D. Đoković1, Miloš Ž. Petrović ${ }^{1}$ \\ Milanko Šekler², Bojana Tešović \\ ${ }^{1}$ Faculty of Agronomy in Čačak, University of Kragujevac, Cara Dušana 34, 32000 Čačak, Republic of Serbia \\ ${ }^{2}$ Veterinary Specialized Institute "Kraljevo", Žička 34, 36000 Kraljevo, Republic of Serbia \\ *Corresponding author: vkurcubic@kg.ac.rs
}

Received 14 June 2020; Accepted 9 July 2020

\begin{abstract}
A B S T R A C T
Viral and bacterial agents causing bovine respiratory disease complex (BRDC) were examined over a five-year period (20152019). Thirty-eight farms of beef and dairy cattle from Central Serbia which showed symptoms of BRDC were observed. A total of 118 nasal swab specimens collected from diseased bullocks $(n=55)$, cows $(n=18)$ and calves $(n=45)$ were chosen for the isolation of bacteria and identification by aerobic cultivation. The most commonly isolated bacterial pathogen was Pasteurella multocida (72.88\% positive samples). Disk-diffusion method (antibiogram) showed that Amoxiclav and Enrofloxacin were the most efficient antibiotics against Pasteurella multocida isolates ( $66.67 \%$ and $54.17 \%$, respectively). From all examined samples, using the Real Time RT-PCR and PCR methods, we determined the genome sequences of bovine respiratory syncytial virus (BRSV- 34.78\% of tested samples (8/23), bovine viral diarrhea virus (BVDV, in 34.37\% (11/32) and Mycoplasma spp. in 33.33\% (8/24). The genome of BoHV-1 virus was not detected in any of the 19 samples tested by Real Time PCR method.
\end{abstract}

Keywords: Bovine respiratory disease complex (BRDC), viruses, bacteria, Mycoplasma spp.,molecular methods, isolation, resistance.

\section{И 3 В О д}

Током петогодишњег периода (2015-2019) испитивани су вирусни и бактеријски узрочници комплекса респираторног обољења говеда (BRDC). Опсервирано је тридесет осам фарми товних и млечних говеда из централне Србије, на којима су запажени симптоми BRDC. Укупно 118 узорака носних брисева пореклом од оболеле товне јунади (н=55), крава (н=18) и телади $(\mathrm{H}=45)$ било је одабрано за изолацију бактерија и детерминацију аеробном култивацијом. Најчешће изоловани бактеријски патоген је била Pasteurella multocida (72.88\% позитивних узорака). Диск-дифузиони метод (антибиограм) указује на то да су Amoxiclav и Enrofloxacin најефикаснији антибиотици против изолата Пастеурелла мултоцида (66,67\% и 54,17\%, наведеним редом). Применом Real Time RT-PCR и PCR метода, из свих испитиваних узорака детерминисане су секвенце генома бовиног респираторног синцицијалног вируса (BRSV $-34,78 \%$ испитиваних узорака-8/23), вирус говеђе вирусне дијареје у 34.37\%, (11/32), Мусорlasma spp. у 33,33\% (8/24). Genom BoHV-1 вируса није утврђен ни у једном од 19 испитиваних узорака, методом Real Time PCR.

Кључне речи: комплекс респираторног обољења говеда (BRDC), вируси, бактерије, Мусорlasта sрр., молекуларне методе изолација, отпорност.

\section{Introduction}

BRDC is one of the most significant causes of cattle morbidity and mortality, both in beef and dairy cattle, causing enormous costs for the cattle industry, which are also reflected in reduced production, increased labor costs and reduced carcass value, regardless of the use of modern vaccines and antibiotics (Irsik et al., 2006; Gershwin et al., 2015). BRDC is caused by one or more of several viruses: bovine respiratory syncytial virus (BRSV), bovine herpes type 1 (BoHV-1) also known as infectious bovine rhinotracheitis (IBR)/infectious pustular vulvovaginitis (IPV), and bovine viral diarrhea virus (BVDV), which predispose animals to coinfection with one or more bacteria, including Pasteurella multocida (P. multocida), Mannheimia haemolytica (M. haemolytica), Mycoplasma bovis (M. bovis), and Histophilussomni (Gershwin et al.,
2015). Viral agents such as BRSV and bovine parainfluenza virus 3 (BPIV-3) are designated as the most common challengers of BRDC. The pathogenesis of BRDC is still largely an enigma for researchers, particularly in the advanced stage of chronic disease, in addition to coinfection with other primary bacterial agents like $M$. bovis (Mehinagic et al., 2019).

BRDC is a multifactorial process due to infectious agents including viruses, bacteria and mycoplasma (Taylor et al., 2010). The development of BRDC is the result of complex and under-researched interactions between the environment, cattle, and pathogens (Setiyaningsih et al., 2018). There has been a more recent approach to addressing these gaps and authors identified signatures of tissue-specific transcriptional responses indicative of tropism in the coordination of host's immune tissue responses to infection by viral or bacterial infections, and showed that this tissue tropism in host transcriptional response to BRDC 
pathogens results in the activation of different networks of response genes. The results of the above mentioned research serve as a basis for the development of innovative therapeutic strategies and for the selection of cattle with enhanced resistance to BRDC (Behura et al., 2017).

The most commonly reported predisposing factors that facilitate the onset of BRDC are: stress, weaning, inadequate (mostly too high) temperature, inappropriate stocking density, dust, humidity, shipping and frequent dietary changes (Taylor et al., 2010). Other researchers have concluded that the major viral pathogens associated with BRDC that primarily cause respiratory lesions are BoHV-1, BRSV and BPIV-3 (Kirchhoff et al., 2014). Unique among the bovine respiratory viral agents is BVDV, because intrauterine infection can lead to cattle that are persistently infected (PI), chronically ill or dying in feedlots (Kurćubić et al., 2011). BVDV infections have an immunosuppressive effect and facilitate the onset of BRDC, primarily due to the creation of favorable conditions for the development of bacterial agents, the most common of which are: sixteen serotypes of $M$. haemolytica, P. multocida, Histophilus somni, Streptococcus pneumoniae, Staphylococcus aureus, Corynebacterium bovis, Streptococcus spp. and Micrococcus spp. (Taylor et al.,2010). Mycoplasmas caused serious disease in cattle, with significant negative economic and welfare impacts (Parker et al., 2018). M. bovisis currently recognized as one of the most important and frequently isolated Mycoplasma species associated with cattle disease worldwide (Bednarek et al., 2012; Fox, 2012). Other frequently isolated mycoplasmas are: Mycoplasma bovirhinis, Mycoplasma dispar, Ureaplasma diversum and even Mycoplasma canis (Szymańska et al., 2010).

The aim of our study was to discover the prevalence of bacterial and viral pathogens responsible for BRDC in fattening and dairy cattle of different age categories from a number of farms, as well as to determine the resistance of $P$. multocida to the most commonly used antibiotics/sulfonamides in Serbian veterinary practice.

\section{Material and methods}

The cattle included in the experiment were chosen from 38 farms of fattening bulls and dairy cattle from Central Serbia. Nasal swabs were sampled at the request of the owners, who reported in anamnestic data that the diseased animals showed symptoms of respiratory disease, which seemed to justify the suspicion of BRDC. In addition to routine clinical diagnostics, tests were performed to isolate bacterial and viral pathogens and determine the most effective antibacterial therapy. The anamnestic data were generally very similar for cattle suspected of BRDC: rectal temperature above $40.1{ }^{\circ} \mathrm{C}$, loss of appetite accompanying weight loss, rapid, saccadic breathing, strong dry cough, nasal discharge of serous to mucopurulent appearance, eye discharge in some animals, less mobility and depression. Clinical examination involving auscultation of the lung revealed wheezing.
After anamnesis taking and clinical examination, sampling was performed immediately, from the nasal mucosa, using sterile swabs and test tubes.After sampling, all samples were properly transported in hand-held refrigerators to the receiving department of the Kraljevo Veterinary Specialized Institute, and examined at the Department of Laboratory Diagnostics.

A total of 118 nasal swab specimens taken from diseased bullocks $(n=55)$, cows $(n=18)$ and calves $(n=45)$ were chosen for the isolation of bacteria and identification by aerobic cultivation,with subsequent biochemical identification and determination of the isolated strains (Laboratory Diagnostics Manual; standardization of diagnostic methods for bacterial, viral and parasitic diseases whose control is prescribed by law (1984) and Quinn et al. (2002).

Susceptibility testing of isolated bacterial strains to antibiotics/sulfonamides (antibiogram) was performed using the disk diffusion method, according to the European Committee on Antimicrobial Susceptibility Testing (EUCAST, 2015).

Detection and quantitation of BRSV were performed by Real Time RT-PCR (Boxus et al., 2005). Detection and quantitation of BVD virus were also conducted by Real Time RT-PCR OIE Chapter 2.4.8, section 1., d). Virus genomes were extracted using the QIAamp Viral RNA Mini Kit (Qiagen, Germany). Real Time RT-PCR reaction was performed using the Superscript III Platinum ${ }^{\circledR}$ One-Step Quantitative Real Time RT-PCR System (Invitrogen, USA), the Real Time PCR machine AriaMx (Agilent), according to the protocol described by Baxi et al. (2006).

The genome of the virus IBR/IPV was extracted using the QIAamp DNA Mini Kit (Qiagen, Germany). Real Time PCR reaction was performed using the Maxima $^{\mathrm{TM}}$ Probe qPCR Master Mix (Fermentas, Lithuania), the Real Time PCR machine AriaMx (Agilent), according to the protocol described in the OIE Manual, Chapter 2.4.13 section 1., c).

Rapid detection of Mycoplasma spp. was performed using a Bio Rad PCR machine according to the method described by Hotzel et al. (1996). DNA fragments were separated by horizontal electrophoresis in a $2 \%$ agarose-gel (E-Gel iBase Power System, Israel), at $48 \mathrm{~V}, 0.8 \mathrm{~A}, 50 / 60 \mathrm{~Hz}$ for around 30 min. Gels were illuminated and photographed in a chamber (Gel Doc XR System with Image Lab, Bio-Rad) using UV light.

\section{Results and discussion}

Results of the microbiological tests and susceptibility testing of $P$. multocidaisolates to antibiotics and sulfonamides (antibiogram) are presented in the Tables below (1-2).

The most common isolated bacterial pathogen was P. multocida (72.88\%-86/118), and we tested its susceptibility to antibiotics and sulfonamides (Table 2). Other tested bacterial agents were less present, as shown in descending order: Streptococcus spp. (47.46\%-56/118); Corynebacterium spp. (27.97\%33/118); M. haemolytica (24.58\%-29/118); Neisseria spp. (22.03\%-26/118); Staphylococcus epidermidis (11.02\%-13/118) and Klebsiella spp. (4.24\%-5/118). 
Table 1

Microbiological tests (bacteriological and virological) of samples of nasal swabs from cattle

\begin{tabular}{|c|c|c|c|c|c|c|c|c|c|c|c|c|c|c|c|}
\hline હ્ّ & 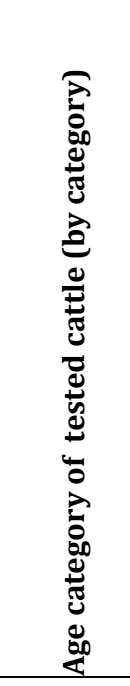 & 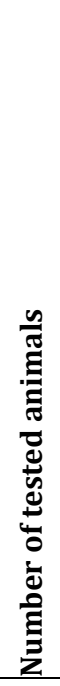 & 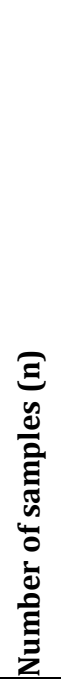 & 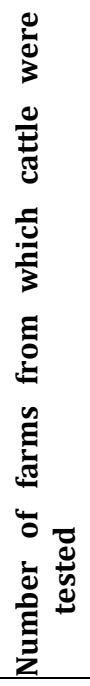 & 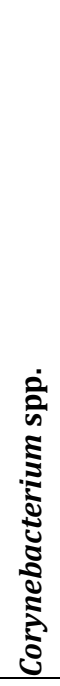 &  & 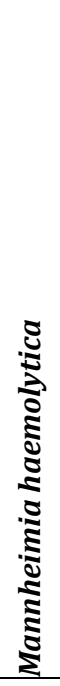 & 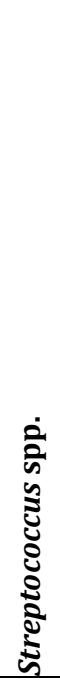 & 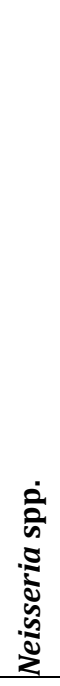 & 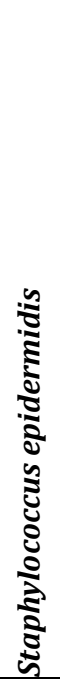 & 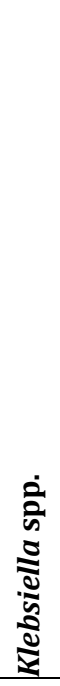 & 蒙 & 方 & 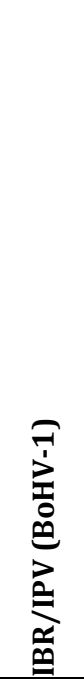 & 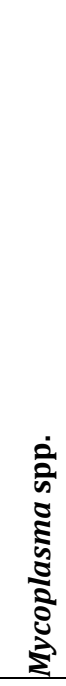 \\
\hline 2015 & $\begin{array}{l}\text { Bullocks } \\
\text { Cows } \\
\text { Calves }\end{array}$ & $\begin{array}{l}4 \\
6 \\
5 \\
\end{array}$ & 15 & 5 & 4 & 15 & 3 & 10 & 3 & 0 & 0 & $*_{-}$ & - & - & - \\
\hline 2016 & $\begin{array}{l}\text { Bullocks } \\
\text { Cows } \\
\text { Calves }\end{array}$ & $\begin{array}{c}24 \\
7 \\
12 \\
\end{array}$ & 43 & 11 & 13 & 32 & 13 & 26 & 14 & 6 & 0 & $\begin{array}{l}* * 2 \\
(2)\end{array}$ & $\begin{array}{c}0 \\
(2)\end{array}$ & $\begin{array}{c}0 \\
(1)\end{array}$ & $\begin{array}{c}0 \\
(2)\end{array}$ \\
\hline 2017 & $\begin{array}{l}\text { Bullocks } \\
\text { Cows } \\
\text { Calves }\end{array}$ & $\begin{array}{l}4 \\
0 \\
6\end{array}$ & 10 & 5 & 3 & 4 & 1 & 0 & 1 & 0 & 0 & $\begin{array}{c}0 \\
(6)\end{array}$ & $\begin{array}{c}0 \\
(6)\end{array}$ & $\begin{array}{c}0 \\
(4)\end{array}$ & $\begin{array}{c}0 \\
(4)\end{array}$ \\
\hline 2018 & $\begin{array}{l}\text { Bullocks } \\
\text { Cows } \\
\text { Calves }\end{array}$ & $\begin{array}{c}20 \\
5 \\
17\end{array}$ & 42 & 14 & 10 & 27 & 11 & 15 & 6 & 7 & 0 & $\begin{array}{c}6 \\
(15)\end{array}$ & $\begin{array}{c}11 \\
(19)\end{array}$ & $\begin{array}{c}0 \\
(15)\end{array}$ & $\begin{array}{c}3 \\
(13)\end{array}$ \\
\hline 2019 & $\begin{array}{l}\text { Bullocks } \\
\text { Cows } \\
\text { Calves }\end{array}$ & $\begin{array}{l}3 \\
0 \\
5\end{array}$ & 8 & 3 & 3 & 8 & 1 & 5 & 2 & 0 & 5 & $\begin{array}{c}0 \\
(2)\end{array}$ & $\begin{array}{c}0 \\
(5)\end{array}$ & $\begin{array}{c}0 \\
(3)\end{array}$ & $\begin{array}{c}5 \\
(5)\end{array}$ \\
\hline
\end{tabular}

$* *$ not tested

**2 the upper number represents the number of positive swabs, relative to the number of samples tested (in parentheses)

The presence of the IBR/IPV virus genome in our study was not determined in any of the 19 examined samples, during 2017. and 2018. The BRSV genome was determined in $34.78 \%$ of examined samples (8/23). The findings of Brodersen (2010) showed that BRSV is a major cause of respiratory disease and a major contributor to BRDC. In our examination, the BVDV genome was detected in $34.37 \%$ of the tested samples (11/32). Mycoplasma spp. was found in $33.33 \%$ of the examined samples $(8 / 24)$, in our study. More recently, BPIV-3 has been found to be the predominant causative agent of single infections in 39 cases, and of coinfection with $M$. bovisin 39 cases as well. The comparison of the detection methods for $M$. bovis showed that Real Time PCR was more specific and sensitive than immunohistochemistry (IHC). BPIV-3 and $M$. bovis persisted in chronic BRDC, unlike BRSV, suggesting permanent damage to the defense mechanisms in the lungs (Parker et al., 2018; Mehinagic et al., 2019).

Results similar to ours were published by other authors: Härtel et al. (2004); Zaher et al. (2014); Setiyaningsih et al. (2018); Karayel Hacioğlu et al. (2019).

The data presented in Table 2 indicate that the most efficient antibiotics against P. multocida isolates were Amoxiclav and Enrofloxacin $(66.67 \%$ and $54.17 \%$ sensitive isolates, respectively), in contrast to previous studies by Kurćubić et al. (2013), in which P. multocida was most sensitive to Enrofloxacin and Floron $(100 \%$ of examined isolates sensitive to both antibiotics).

Hence, strict screening of antimicrobial susceptibility is a key measure for the selection of effective cattle pneumonia medicament treatment (Katsuda et al., 2009). 
Table 2

Susceptibility testing of P. multocida isolates to antibiotics and sulfonamides (antibiogram)

\begin{tabular}{|c|c|c|c|c|c|c|c|c|c|c|}
\hline \multirow{2}{*}{$\begin{array}{l}\text { Antibiotics/sulfonamides } \\
\text { Amoxicillin }\end{array}$} & \multicolumn{2}{|c|}{ *S $2015 \mathrm{R}$} & \multicolumn{2}{|c|}{ S 2016 R } & \multicolumn{2}{|c|}{ S $2017 \mathrm{R}$} & \multicolumn{2}{|c|}{ S $2018 \mathrm{R}$} & \multicolumn{2}{|c|}{ S 2019 R } \\
\hline & 4 & 9 & 23 & 12 & 5 & 4 & 10 & 21 & 5 & 3 \\
\hline Amoxiclav & 9 & 4 & 23 & 12 & 2 & 7 & 25 & 6 & 5 & 3 \\
\hline Ampicillin & 8 & 5 & 23 & 12 & 2 & 7 & 13 & 18 & 5 & 3 \\
\hline Penicillin & 2 & 11 & 19 & 16 & 0 & 9 & 14 & 17 & 0 & 8 \\
\hline Gentamicin & 5 & 8 & 7 & 28 & 0 & 9 & 1 & 30 & 0 & 8 \\
\hline Enrofloxacin & 9 & 4 & 22 & 13 & 2 & 7 & 16 & 15 & 3 & 5 \\
\hline Tetracycline & 0 & 13 & 4 & 31 & 5 & 4 & 2 & 29 & 0 & 8 \\
\hline $\begin{array}{l}\text { Trimethoprim+ } \\
\text { sulphomethoxasole }\end{array}$ & 0 & 13 & 0 & 35 & 0 & 9 & 1 & 30 & 0 & 8 \\
\hline Floron & 2 & 11 & 14 & 21 & 1 & 8 & 2 & 29 & 2 & 6 \\
\hline Total swabs tested & \multicolumn{2}{|c|}{13} & \multicolumn{2}{|c|}{35} & \multicolumn{2}{|c|}{9} & \multicolumn{2}{|c|}{31} & \multicolumn{2}{|c|}{8} \\
\hline
\end{tabular}

*S - Sensitive; R - Resistant

\section{Conclusions}

The most common bacterial findings were $P$. multocida, Streptococcus spp., Corynebacterium spp., $M$. haemolytica, Neisseria spp., Staphylococcus epidermidis and Klebsiella spp., suggesting their greater importance for BRDC in Serbian cattle compared with $M$. haemolytica, which is the predominant pathogen worldwide. In the future, research will be focused on determining how these pathogens interact with each other.According to Real Time RT-PCR findings, BRSV and BVDV are common viruses in Serbian cattle herds suffering from BRDC (the BoHV-1 genome was not identified in our study). Mycoplasma spp. was found in $33.33 \%$ of the examined samples $(8 / 24)$, in our study. The most efficient antibiotics against $P$. multocida isolates were Amoxiclav and Enrofloxacin $(66.67 \%$ and $54.17 \%$ sensitive isolates, respectively).

\section{Acknowledgment}

This research was financially supported by the Ministry of Science and Technological Development, Republic of Serbia, TR 31001 project.

\section{References}

Baxi, M., McRae, D., Baxi, S., Greiser-Wilke, I., Vilcek, S., Amoakoa, K., Deregt, D. (2006). A one-step multiplex realtime RT-PCR for detection and typing of bovine viral diarrhea viruses. Veterinary Microbiology, 116(1-3), 25 37-44.

Bednarek, D., Szymańska-Czerwińska, M., Dudek, K. (2012). Bovine Respiratory Syndrome (BRD) Etiopathogenesis, Diagnosis and Control, A Bird's-Eye View of Veterinary Medicine, Dr. Carlos C. Perez-Marin (Ed.), ISBN: 978-95351-0031-7, InTech.

Behura, S.K., Tizioto, P.C., Kim, J., Grupioni, N.V., Seabury, C.M., Schnabel, R.D., Gershwin, L.J., Van Eenennaam, A.L., ToaffRosenstein, R., Neibergs, H.L., Luciana, C.A., Regitano, L.C.A., Taylor, J.F. (2017). Tissue Tropism in Host Transcriptional Response to Members of the Bovine Respiratory Disease Complex. Scientific Reports, 7, 17938

Boxus, M., Letellier, C., Kerkhofs, P. (2005). Real-time RT-PCR for the detection and quantitation of bovine respiratory syncicyal virus. Journal of Virological Methods, 125, 125130.

EUCAST and Comite de l' antibiogramme de la Societe Francaise de Microbilogie: Recommandations 2015.

Fox, L.K. (2012). Mycoplasma mastitis: causes, transmission, and control. Veterinary Clinics of North America: Food Animal Practice, 28, 225-237.
Gershwin, L.J., Van Eenennaam, A.L., Anderson, M.L., McEligot, H.A., Shao, M.X., Toaff-Rosenstein, R., Taylor, J.F., Neibergs, H.L., Womack, J. (2015). Single Pathogen Challenge with Agents of the Bovine Respiratory Disease Complex. PLoS ONE 10(11), e0142479.

Karayel Hacioğlu, İ., Coşkun, N., Duran Yelken, S., Sevinç, S., Alkan, F. (2019). Phylogenetic analysis of Bovine Respiratory Syncytial Virus from calves with respiratory disorders. Kafkas Universitesi Veteriner Fakultesi Dergisi, 25(2), 251-256.

Härtel, H., Nikunen, S., Neuvonen, E., Tanskanen, R., Kivelä, S.L., Aho, P., Soveri, T., Saloniemi, H. (2004). Viral and Bacterial Pathogens in Bovine Respiratory Disease in Finland. Acta Veterinaria Scandinavica, 45, 193-200.

Hotzel, H., Sachse, K., Pfützner, H. (1996). Rapid detection of Mycoplasma bovis in milk samples and nasal swabs using the polymerase chain reaction. Journal of Applied Microbiology, 80, 505-510.

Irsik, M., Langemeier, M., Schroeder, T., Spire, M., Roder, J.D. (2006). Estimating the effects of animal health on the performance of feedlot cattle. Bovine Practitioner, 40, 6574.

Katsuda, K., Kohmoto, M., Mikami, O., Uchida, I. (2009). Antimicrobial resistance and genetic characterization of fluoroquinolone-resistant Mannheimia haemolytica isolates from cattle with bovine pneumonia. Veterinary Microbiology, 10, 10-6.

Kirchhoff, J., Uhlenbruck, S., Goris, K., Keil, G.M., Herrler, G. (2014). Three viruses of the bovine respiratory disease complex apply different strategies to initiate infection. Veterinary Research, 45, 20.

Kurćubić, V., Petrović, T., Đoković, R., Ilić, Z., Petrović, M.D. (2011): Antibody response of beef calves to experimental monovalent and multivalent inactivated bovine viral diarrhoea virus vaccines as measured by indirect ELISA method. Biotechnology in Animal Husbandry, 27(3), book 2, 901-911.

Kurćubić, V.S., Đoković, R.D., Vidanović, D., Šekler, M., Matović, K., Ilić, Z., Stojković, J. (2013). Bovine respiratory disease complex (BRDC): viral and bacterial pathogens in Serbia. Biotechnology in Animal Husbandry, 29(1), 29-36.

MANUAL OF STANDARDS FOR DIAGNOSTIC TEST AND VACCINES, Chapter 2.4 .8 and 2.4.13 - Determining the presence of BVD virus genome (RT- PCR) and determining the presence of IBR/IPV virus genome (Real Time PCR) (2008). $6^{\text {th }}$ Edition, Office International des epizooties, World organisation for animal health, OIE, Paris.

Mehinagic, K., Pilo, P., Vidondo, B., Stokar-Regenscheit, N. (2019). Coinfection of Swiss cattle with bovine parainfluenza virus 3 and Mycoplasma bovis at acute and chronic stages of bovine respiratory disease complex. Journal of Veterinary Diagnostic Investigation, 31(5), 674680.

Laboratory Diagnostics Manual; standardization of diagnostic methods for bacterial, viral and parasitic diseases whose control is prescribed by law, Belgrade, 1984. 
Parker, A.M., Sheehy, P.A., Hazelton, M.S., Bosward, K.L., House, J.K. (2018). A review of mycoplasma diagnostics in cattle. Journal of Veterinary Internal Medicine, 32, 1241-1252.

Quinn, P.J., Markey, B.K., Carter, M.E., Donnelly, W.J., Leonard, F.C. Veterinary Microbiology and Microbial Disease. Iowa State University Press, Ames, Iowa, USA, 2002. 536 pp. ISBN 0-632-05525-1.

Setiyaningsih, S., Shofa M., Wulansari, R., Priosoeryanto, B.P. (2018). Preliminary Investigation of Bovine Respiratory Disease Complex in Indonesia. Proceeding of the 20th FAVA CONGRESS \& The 15th KIVNAS PDHI, Bali Nov 1-3, 2018.
Szymańska-Czerwińska, M., Dudek, K., Bednarek, D. (2010). Occurrence and diagnosis of mycoplasma infections in ruminants. Medycyna weterynaryjna, 66, 597-599.

Taylor, J.D., Fulton, R.W., Lehenbauer, T.W., Step, D.L., Confer, A.W. (2010). The epidemiology of bovine respiratory disease: What is the evidence for predisposing factors? Canadian Veterinary Journal, 51, 1095-1102.

Zaher, K.S., Syame, S.M., Hanan, M. Elhewairy, H.M., Marie, H.S.H. (2014). Investigation of Bovine Respiratory Disease Complex in Egypt with Emphasis on Some Viral and Bacterial Pathogens. Life Science Journal, 11,(6), 5662. 